\title{
Distribution of insertion sequence IS200 among different clonal lines of the related Salmonella serotypes Livingstone and Eimsbuettel
}

\author{
PAMELA B. CRICHTON, D. C. OLD and HANNAH F. MORPHY \\ Department of Medical Microbiology, University of Dundee Medical School, Ninewells Hospital, Dundee \\ DD1 9SY
}

\begin{abstract}
The copy number and genetic location of IS200 have provided evidence of strain relatedness in many serotypes of Salmonella. In this study, 100 isolates of the related serotypes Livingstone $(6,7: \mathrm{d}: \mathrm{l}, \mathrm{w})$ and Eimsbuettel $(6,7, \underline{14}: \mathrm{d}: 1, w)$, representing 10 ribotype/biotype (RT/BT) groups isolated from human and non-human sources in seven countries over a 26-year period, were examined for their IS200 profiles. The distribution of IS200 in strains of these serotypes was limited, being present in all 53 isolates of ribotype 1 (RT1) and its variant type RT6, in one of five isolates of RT5 but in none of 42 isolates of RTs 2,3 or 4 . Although the seven IS200 profiles identified in RT1 isolates were of little value for further discrimination within different biotype groups, they were extremely valuable for confirming serotype: isolates of RT1/BT8/ IS200 profile A (or its variants) and those of RT1/BT3/IS200 profile B (or its variants) were almost invariably associated with serotypes Livingstone and Eimsbuettel, respectively.
\end{abstract}

\section{Introduction}

The mobile genetic element IS200 is widely distributed on conserved loci on the chromosome of many, but not all, serotypes of Salmonella [1-3]. The copy number and location of IS200 may change over time, and identity among strains in the number and position of IS200 provides evidence of their common genetic ancestry $[4,5]$. Thus, the use of IS200 fingerprinting has become increasingly popular for discrimination of strains and identification of clones in many Salmonella serotypes [reviewed in 4,5].

Because the prevalence of human infection by the serologically similar serotypes Livingstone (antigenic formula $6,7: \mathrm{d}: 1, \mathrm{w})$ and Eimsbuettel $(6,7,14: \mathrm{d}: 1, \mathrm{w})$ is generally low in the UK, serotype-specific phagetyping schemes have never been developed for either serotype. Hence, when faced with major outbreaks of human infection in Scotland by Eimsbuettel [6] and Livingstone [7], a multiple typing approach was used - with biotyping, plasmid profiling and ribotyping to identify the epidemic clones involved $[8,9]$.

This report presents the findings of a study on

Received 13 Nov. 1997; accepted 13 Jan. 1998.

Corresponding author: Dr D. C. Old. the distribution of IS200 among the strains of Livingstone and Eimsbuettel of different ribotype/biotype (RT/BT) groups and provides further evidence of the genetic relatedness of strains of these two serologically similar serotypes.

\section{Materials and methods}

\section{Bacteria}

Of the 166 isolates of Livingstone reported previously [8], 56 were selected for IS200 analysis. The properties of these isolates, which include representatives of seven different ribotype/biotype (RT/BT) groups isolated at different times and from various sources in six countries, are shown in Table 1. Of the 100 isolates of Eimsbuettel reported previously [9], 44 were selected for IS200 analysis, including representatives of eight different RT/BT groups isolated at different times and from various sources in seven countries (Table 2 ).

All isolates were serotyped at the Scottish Salmonella Reference Laboratory, Glasgow. In this report, those with the antigenic formula 6,7:d:1,w are designated serotype Livingstone and those with the antigenic formula $6,7, \mathrm{c} 14: \mathrm{d}: 1, \mathrm{w}$ as serotype Eimsbuettel, as is the practice in both UK Salmonella Reference Laboratories. 
Table 1. Details of 56 isolates of Salmonella serotype Livingstone examined

\begin{tabular}{lccl}
\hline Country of origin & Years of isolation & RT/BT group & Source (number of isolates) \\
\hline Scotland & $1985-1993$ & $1 / 8$ & Man (13), poultry (4), water (1) \\
England and Wales & $1984-1992$ & $1 / 3$ & Poultry (2), man (1) \\
& & $1 / 8$ & Poultry (3), man (1) \\
& & $2 / 1$ & Man (5), egg (3), poultry (2) \\
& & $3 / 5$ & Poultry (1) \\
Canada & $4 / 5$ & Man (1), poultry (1) \\
France & Not known & $3 / 5$ & Poultry (2), animal feed supplement (1) \\
& $1990-1991$ & $1 / 3$ & Egg (1), man (1) \\
Israel & & $1 / 8$ & Delicatessen (1), man (1), water (1) \\
& $2 / 1$ & Egg (1) Unspecified (1) \\
& $1968-1992$ & $1 / 7$ & Animal feed (1) \\
& & Feed meal (1) \\
& & $3 / 5$ & Man (1) beef (1), pet meal (1), unspecified (1) \\
\hline
\end{tabular}

Table 2. Details of 44 isolates of Salmonella serotype Eimsbuettel examined

\begin{tabular}{|c|c|c|c|}
\hline Country of origin & Years of isolation & $\mathrm{RT} / \mathrm{BT}$ group & Source (number of isolates) \\
\hline \multirow[t]{4}{*}{ Scotland } & $1977-1990$ & $1 / 3$ & Man (9), poultry (5), environment (1), pig (1), thermometer (1), water (1) \\
\hline & & $2 / 1$ & Man (5), poultry (1) \\
\hline & & $3 / 5$ & Man (2), poultry (1) \\
\hline & & $6 / 3$ & Man (1) \\
\hline \multirow{5}{*}{ England and Wales } & 1984-1992 & $1 / 3$ & Poultry (1) \\
\hline & & $2 / 1$ & Animal feed (1), meat/bone meal (1) \\
\hline & & $2 / 3$ & Poultry (1) \\
\hline & & $3 / 5$ & Meat/bone meal (1) \\
\hline & & $4 / 5$ & Man (1) \\
\hline \multirow{2}{*}{ Australia } & 1991 & $3 / 5$ & Cotton seed meal (1) \\
\hline & & $3 / 6$ & Bone meal (1) \\
\hline \multirow[t]{3}{*}{ Canada } & $1989-1990$ & $3 / 5$ & Poultry (1) \\
\hline & & $3 / 6$ & Animal feed (1), bone meal (1) \\
\hline & & $4 / 5$ & Cat (1) \\
\hline \multirow[t]{2}{*}{ France } & 1990-1991 & $1 / 8$ & Poultry (1) \\
\hline & & $3 / 5$ & Unspecified animal (1), fish (1) \\
\hline Israel & 1972 & $3 / 5$ & Unspecified (1) \\
\hline
\end{tabular}

Cultures were stored on Dorset's egg slopes at room temperature $\left(18-20^{\circ} \mathrm{C}\right)$ until they were subcultured on MacConkey Agar (Oxoid).

\section{DNA extraction}

DNA was extracted by a modification of the method described previously [10]. One colony from a 24-h culture on MacConkey agar was inoculated into $\mathrm{L}$ broth [11] $(10 \mathrm{ml})$ in a $20-\mathrm{ml}$ screw-capped plastic bottle and incubated with shaking $(100 \mathrm{rpm})$ at $37^{\circ} \mathrm{C}$ for $18 \mathrm{~h}$. The culture, cooled on ice, was centrifuged at $3000 \mathrm{~g}$ for $20 \mathrm{~min}$; the cell pellet was resuspended in $650 \mu 1$ of TE buffer (10 mM Tris, $1 \mathrm{mM}$ EDTA, pH 8.0) and transferred to a $2-\mathrm{ml}$ microfuge tube to which $40 \mu \mathrm{l}$ of $\operatorname{SDS} 10 \% \mathrm{w} / \mathrm{v}$ and $4 \mu \mathrm{l}$ of proteinase $\mathrm{K}$ $20 \mathrm{mg} / \mathrm{ml}$ were added. After incubation at $50^{\circ} \mathrm{C}$ for $1 \mathrm{~h}, 100 \mu \mathrm{l}$ of $5 \mathrm{M} \mathrm{NaCl}$ and $100 \mu \mathrm{l}$ of $\mathrm{CTAB}$ solution (CTAB $10 \% \mathrm{w} / \mathrm{v}$ in $0.7 \mathrm{M} \mathrm{NaCl}$ ) were added and the tube was shaken to mix the contents before incubation at $65^{\circ} \mathrm{C}$ for $20 \mathrm{~min}$. Chloroform:isoamyl alcohol $(24: 1)$ $(1 \mathrm{ml})$ was added and the tube was shaken thoroughly and centrifuged at $6000 \mathrm{~g}$ for $10 \mathrm{~min}$. Supernate was transferred gently to a $1.5-\mathrm{ml}$ microfuge tube. After repeating the chloroform-extraction step, 0.6 volumes of cold $\left(-20^{\circ} \mathrm{C}\right)$ isopropanol were added and the tube was inverted several times. Precipitated DNA was transferred gently to a tube containing $1 \mathrm{ml}$ of ethanol $70 \% \mathrm{v} / \mathrm{v}$. The tube was centrifuged at $12000 \mathrm{~g}$ for $5 \mathrm{~min}$ and the supernate was discarded. The DNA pellet was dried at $37^{\circ} \mathrm{C}$ in the open tube and dissolved in $\geqslant 100 \mu \mathrm{l}$ of TE buffer ( $\mathrm{pH} 8.0$ ).

\section{DNA digestion and transfer to nylon membranes}

DNA $(c .2 \mu \mathrm{g})$ was digested to completion with Pst $\mathbf{I}$ (Promega, Southampton), a restriction endonuclease with no recognition site within the IS200 sequence $[3,12]$. Digests were electrophoresed at $2 \mathrm{~V} / \mathrm{cm}$ in TBE buffer $(0.089 \mathrm{M}$ Tris- $\mathrm{HCl}, 0.089 \mathrm{M}$ boric acid, $0.002 \mathrm{M}$ EDTA), along with digoxigenin (DIG)-labelled lambda DNA digested with Eco RI and Hind III (Boehringer Mannheim) through agarose (Oxoid Type 1: Low EEO from Unipath, Basingstoke, Hants) $0.8 \% \mathrm{w} / \mathrm{v}$, containing ethidium bromide $0.5 \mu \mathrm{g} / \mathrm{ml}$. DNA fragments were transferred to Positive Membrane (Appligene Oncor, Birtley, Chester-le-Street, Co. Durham) on TransDNA Express (Appligene) for $75 \mathrm{~min}$ at 55 mbar with $20 \times$ SSC buffer [13] and fixed by UV light $(312 \mathrm{~nm})$ for $5 \mathrm{~min}$. 


\section{Hybridisation and detection by chemiluminescence}

A PCR-generated 692-bp DNA probe of IS200 $[12,14]$ was labelled with digoxigenin-11-dUTP by random priming (Boehringer Mannheim) and a 'mock' hybridisation was performed to optimise the amount of DIGlabelled probe per $\mathrm{ml}$ of prehybridisation solution. Prehybridisation, hybridisation and detection of hybrids with anti-DIG alkaline phosphatase and $\operatorname{CSPD}^{(\mathbb{R})}$ were performed as recommended by the manufacturer (Boehringer Mannheim) except that boiled, sheared salmon sperm DNA $50 \mu \mathrm{g} / \mathrm{ml}$ was included in prehybridisation and hybridisation solutions.

\section{Results}

When the 100 isolates of Salmonella of serotypes Livingstone and Eimsbuettel were analysed in Southern hybridisation with the 692 -bp IS200 probe, 54 were found to contain IS 200 . Thus, $33(60 \%)$ of 56 isolates of Livingstone and $21(48 \%)$ of 44 isolates of Eimsbuettel contained between two and seven copies of IS200 (Figs. 1 and 2). In all, eight different IS200 hybridisation profiles were detected (Fig. 2), each

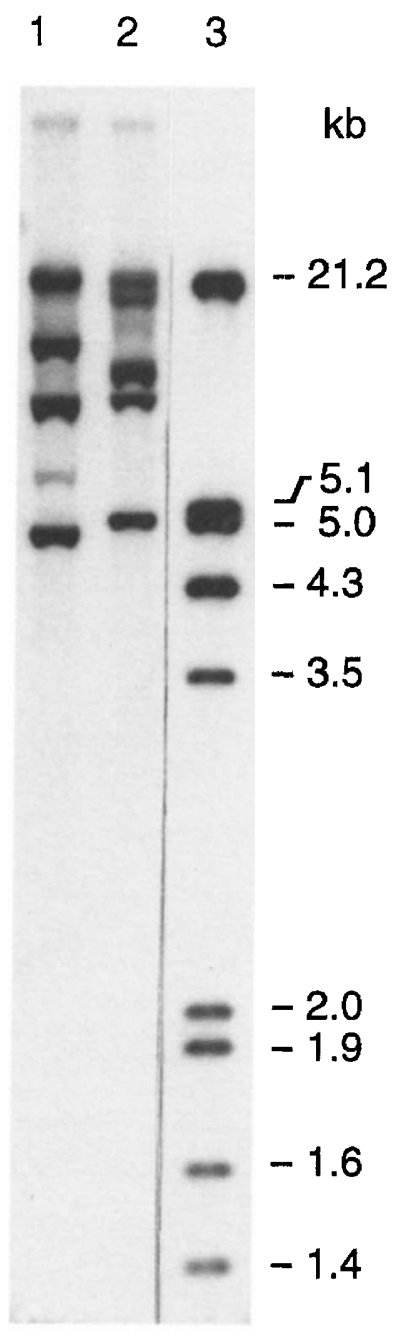

Fig. 1. Southern blot analysis: lanes 1, IS200 profile A; 2, IS 200 profile $\mathrm{B} ; \mathbf{3}$, mol. size markers.
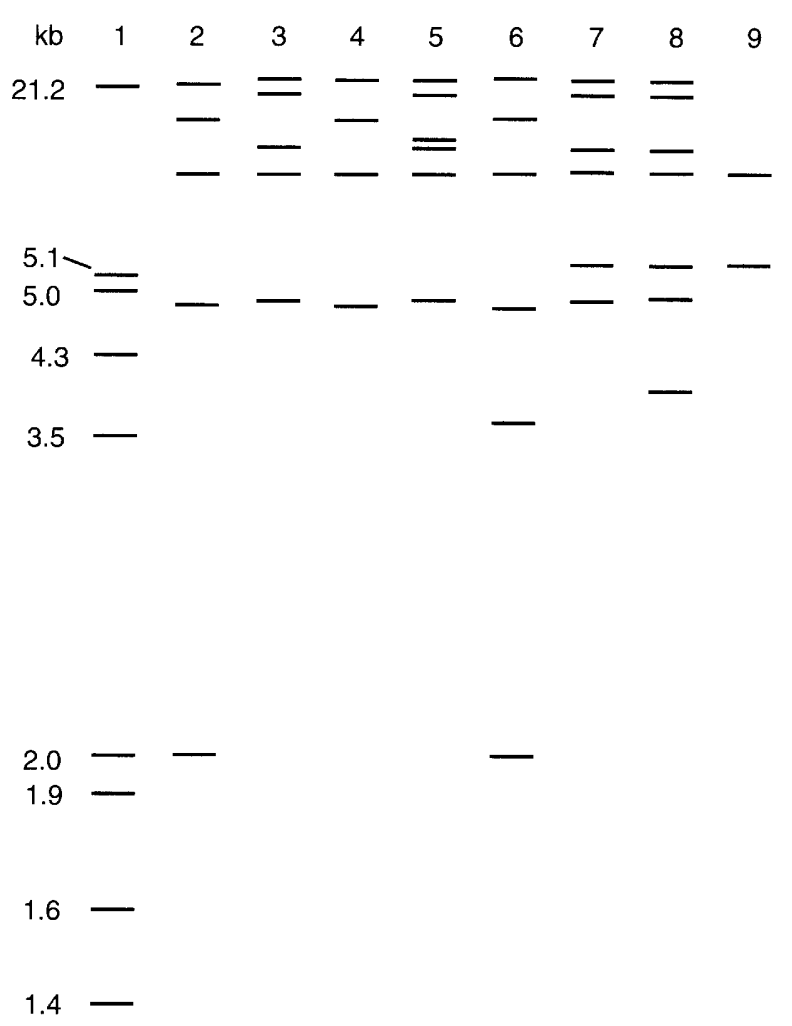

Fig. 2. Line drawing representing the eight IS200 profiles detected among 100 isolates of Salmonella serotypes Livingstone and Eimsbuettel. Lane 1, mol. size markers; 2-9, profiles A, B, C, D, E, F, H and L. Recorded mol. sizes of IS200-containing Pst I DNA fragments are the average of those obtained from up to eight separate gel runs.

containing a conserved band of $6.7 \mathrm{~kb}$. However, two types, designated profile A (19 isolates) and profile B (23), accounted for most (78\%) of the 54 IS200positive isolates. The molecular sizes of the IS200containing Pst I-generated DNA fragments were calculated from the average of those obtained from up to eight different gel runs. Profile A comprised bands of c. $2.0,4.8,6.7,10$ and $\geqslant 21 \mathrm{~kb}$; profile B comprised bands of $c$. 5.0, 6.7, 7.3, 17 and $\geqslant 21 \mathrm{~kb}$. These two major IS200 profiles are compared in Fig. 1.

IS200 profile $\mathrm{C}$, lacking the $2.0-\mathrm{kb}$ fragment $(4.8,6.7$, 10 and $\geqslant 21 \mathrm{~kb}$ ), and profile $\mathrm{E}$, with an additional fragment of c. $3.7 \mathrm{~kb}(2.0,3.7,4.8,6.7,10$ and $\geqslant 21 \mathrm{~kb}$ ), were considered to be variants of IS200 profile A. IS200 profile D, with an additional $8.0-\mathrm{kb}$ fragment $(5.0,6.7,7.3,8.0,17$ and $\geqslant 21 \mathrm{~kb})$, profile $\mathrm{F}$, with an additional 5.5 -kb fragment $(5.0,5.5,6.7$, $7.3, \quad 17$ and $\geqslant 21 \mathrm{~kb}$ ) and profile $\mathrm{H}$, with two additional fragments of 3.8 and $5.5 \mathrm{~kb}(3.8,5.0,5.5$, $6.7,7.3,17$ and $\geqslant 21 \mathrm{~kb}$ ), were considered to be variants of IS200 profile B.

The eighth IS 200 profile, L, which was only distantly related to the other profiles observed (Fig. 2), had only two copies of IS200 in Pst I-generated fragments of c. 5.2 and $6.7 \mathrm{~kb}$. Representations of the eight IS200 profiles are shown in Fig. 2. 


\section{IS200 in Livingstone strains}

The distribution of IS200 among Livingstone isolates from the different epidemic strains (clones) delineated by RT/BT grouping is shown in Table 3 .

All 25 Livingstone isolates of the major clonal group RT1/BT8 (18 from Scotland, four from England and Wales and three from France) were IS200-positive. Fifteen of the 18 Scottish isolates of RT1/BT8, whether or not they carried the $6.5-\mathrm{kb}$ plasmid characteristic of the Scottish epidemic strain [8], showed IS200 profile A. Another three Scottish isolates of RT1/BT8, isolated from patients recently returned from Spain or with a plasmid profile different from that of the Scottish epidemic strain, were also IS200-positive but their profiles were type C (two isolates) or type $\mathrm{E}$ (one). Thus, all $18 \mathrm{Scottish}$ isolates of RT1/BT8, isolated over the 9-year period 19851993 and regardless of source or plasmid profile, had IS200 profile $\mathrm{A}$ or its variants $\mathrm{C}$ or $\mathrm{E}$.

Four Livingstone isolates of RT1/BT8 that were isolated from human or poultry sources in England and Wales during 1984-1991 also had IS200 profile A (one isolate) or its variant $\mathrm{C}$ (three). A further three Livingstone isolates from diverse sources (human, water, delicatessen) in France and obtained during 1990-1991 also had IS200 profile A which was found commonly among Scottish isolates of RT1/BT8 (Table 3). Biotype 7 differs from biotype 8 in only one biotyping property [see 8]. Thus, it was of interest to find that the only isolate of RT1/BT7, from an animal-feed source in Israel, also had IS200 profile C, uncommonly found among isolates of RT1/BT8 (Table 3). Thus, all 26 Livingstone isolates of the RT1/BT8 or related RT1/BT7 groups were IS200positive and regardless of source or country of origin had IS200 profile A (19 isolates) or its recognised variants $\mathrm{C}(6)$ or $\mathrm{E}$ (1) (Table 3).

Whereas the majority of Livingstone isolates belonging to RT1 were of BT8, six belonged to RT1/BT3, a group more commonly associated with Eimsbuettel strains [9]. Like the majority, all six isolates of RT1/BT3 were IS200-positive but had IS200 profile B (five isolates) and D (one) (Table 3). The only other Livingstone isolate that gave a positive hybridisation result with the IS200 probe was one of RT5/BT3 from Israel, isolated originally from pig-feed supplement in the USA. Its IS200 profile, L, was unique, with only two copies of IS200 in Pst I fragments of $c$. 5.2 and $6.7 \mathrm{~kb}$ (Fig. 2).

None of the 19 Livingstone isolates of ribotypes 2, 3 or 4, regardless of biotype, source or country of origin, contained IS200 elements (Table 3).

\section{IS200 in Eimsbuettel strains}

The predominant Eimsbuettel clone present among isolates obtained from diverse sources in the UK during 1986-1991 was RT1/BT3, all 19 isolates of which were IS200-positive with IS200 profile B (18 isolates) or its variant profile $\mathrm{F}$ (one). Whereas the majority of Eimsbuettel isolates belonging to RT1 were of BT3, one belonged to RT1/BT8, the major group associated with Livingstone strains [8]. This Eimsbuettel isolate, from poultry in France in 1991, had IS200 profile C (Table 4), associated with a minority of Livingstone isolates of RT1/BT8 (Table 3) but not those from France that had IS200 profile A.

The only Eimsbuettel isolate of the uncommon RT/BT group RT6/BT3 present in this large series of 100 isolates [9] was one isolated from a baby at the outset of the Glasgow hospital outbreak [6]. RT6 is known to be closely related to RT1 [9]. This isolate of RT6/BT3 had the unique IS200 profile, $\mathrm{H}$, which is related to profiles F and B (Fig. 2). None of the 23 Eimsbuettel isolates of RTs 2, 3, or 4, isolated from

Table 4. Distribution of IS 200 among isolates of differnt ribotype/biotype (RT/BT) groups of Salmonella Eimsbuettel

\begin{tabular}{lccccc}
\hline & & \multicolumn{4}{c}{$\begin{array}{c}\text { Number of IS200-positive } \\
\text { isolates with }\end{array}$} \\
\cline { 3 - 6 } $\begin{array}{l}\text { RT } / \text { BT } \\
\text { group }\end{array}$ & $\begin{array}{c}\text { Number of } \\
\text { isolates }\end{array}$ & $\mathrm{B}$ & $\mathrm{F}$ & $\mathrm{H}$ & $\mathrm{C}$ \\
\hline $1 / 3$ & 19 & 18 & 1 & 0 & 0 \\
$1 / 8$ & 1 & 0 & 0 & 0 & 1 \\
$6 / 3$ & 1 & 0 & 0 & 1 & 0 \\
$2 / 1$ & 8 & 0 & 0 & 0 & 0 \\
$2 / 3$ & 1 & 0 & 0 & 0 & 0 \\
$3 / 5$ & 9 & 0 & 0 & 0 & 0 \\
$3 / 6$ & 3 & 0 & 0 & 0 & 0 \\
$4 / 5$ & 2 & 0 & 0 & 0 & 0 \\
\hline
\end{tabular}

Table 3. Distribution of IS200 among isolates of different ribotype/biotype (RT/BT) groups of Salmonella Livingstone

\begin{tabular}{|c|c|c|c|c|c|c|c|}
\hline \multirow[b]{2}{*}{$\mathrm{RT} / \mathrm{BT}$ group } & \multirow{2}{*}{$\begin{array}{c}\text { Number of } \\
\text { isolates }\end{array}$} & \multicolumn{6}{|c|}{ Number of IS 200 -positive isolates with IS 200 profile } \\
\hline & & A & $\mathrm{C}$ & $\mathrm{E}$ & $\mathrm{B}$ & $\mathrm{D}$ & $\mathrm{L}$ \\
\hline $1 / 8$ & 25 & 19 & 5 & 1 & 0 & 0 & 0 \\
\hline $1 / 7$ & 1 & 0 & 1 & 0 & 0 & 0 & 0 \\
\hline $1 / 3$ & 6 & 0 & 0 & 0 & 5 & 1 & 0 \\
\hline $2 / 1$ & 12 & 0 & 0 & 0 & 0 & 0 & 0 \\
\hline $3 / 5$ & 5 & 0 & 0 & 0 & 0 & 0 & 0 \\
\hline $4 / 5$ & 2 & 0 & 0 & 0 & 0 & 0 & 0 \\
\hline $5 / 3$ & 5 & 0 & 0 & 0 & 0 & 0 & 1 \\
\hline
\end{tabular}


various sources in different countries during 19721996 (Table 2) was IS200-positive (Table 4). In summary, all 53 isolates of the related ribotypes RT1/RT6 were IS200-positive, whereas all but one of 47 isolates of ribotypes RT2-5 were IS 200 -negative (Table 5).

\section{Discussion}

The only antigenic difference between the closely related Salmonella serotypes Livingstone and Eimsbuettel is that the latter produces a cell-wall antigen O14 which is present in Livingstone cultures lysogenised by phage 14 [15]. Deletion of serotype names previously accorded to lysogenised variants of extant serotypes was recommended in the Kauffmann-White scheme [16]; however, that practice is not followed in the UK where both names, e.g., Livingstone and Eimsbuettel, are used [17].

Although the prevalence of human infections by these serotypes in the UK is generally low, each has caused sizeable outbreaks in Scotland [6-9]. All of 114 Livingstone isolates from human and other sources in Scotland during 1985-1993 belonged to RT1, all but one were of BT 8 and most carried a $6.5-\mathrm{kb}$ plasmid characteristic of the Tayside outbreak strain [8].
Indeed, RT1 was the only ribotype present among Livingstone strains from Scotland (Table 6). Again, most $(80 \%)$ of the 67 Eimsbuettel isolates from diverse sources in Scotland in 1968-1993, and including the epidemic strain involved in the Glasgow outbreak [6], belonged to RT1 [9]; a minority (20\%) of Eimsbuettel isolates, particularly those from the East of Scotland, were of RT2 and RT3 [9]. Biotyping readily distinguished isolates of RT1 from Scotland $[8,9]$ : all isolates of Livingstone and Eimsbuettel belonged to BT8 and BT3, respectively (Table 6). Together with plasmid profiling, biotyping also identified poultry as the likely source of human infections caused by Livingstone and Eimsbuettel strains in Scotland [7-9].

The finding that all Livingstone and Eimsbuettel isolates of RT1 from Scotland, regardless of biotype, plasmid profile, source or time of isolation, had IS200 profiles that were type A (or its variants) or type B (or its variants), respectively, confirmed the clonal differences that had already been suggested by biotyping (Table 6). Although both IS200 profiles A and B contained five bands, they were readily distinguishable, having only one common band. Thus, IS200 profiling provided little additional type discrimination of RT1 isolates, there being so few isolates of A variant or $B$ variant profiles. Furthermore, the use of

Table 5. Distribution of IS 200 among 100 isolates of Salmonella of the related serotypes Livingstone and Eimsbuettel

\begin{tabular}{|c|c|c|c|c|c|c|c|c|c|c|}
\hline \multirow{2}{*}{$\begin{array}{l}\text { RT/BT } \\
\text { group }\end{array}$} & \multirow{2}{*}{$\begin{array}{c}\text { Number of } \\
\text { isolates } \\
\text { tested }\end{array}$} & \multicolumn{8}{|c|}{ Number of IS 200 -positive isolates with profile } & \multirow{2}{*}{$\begin{array}{c}\text { Number of } \\
\text { IS } 200^{+} \text {isolates } / \\
\text { number tested }\end{array}$} \\
\hline & & A & $\mathrm{C}^{*}$ & $\mathrm{E}^{*}$ & $\mathrm{~B}$ & $D^{\dagger}$ & $\mathrm{F}^{\dagger}$ & $\mathrm{H}^{\dagger}$ & $\mathrm{L}$ & \\
\hline $1 / 7$ & 1 & 0 & 1 & 0 & 0 & 0 & 0 & 0 & 0 & \\
\hline $1 / 8$ & 26 & 19 & 6 & 1 & 0 & 0 & 0 & 0 & 0 & $53 / 53$ \\
\hline $1 / 3$ & 25 & 0 & 0 & 0 & 23 & 1 & 1 & 0 & 0 & \\
\hline $6 / 3$ & 1 & 0 & 0 & 0 & 0 & 0 & 0 & 1 & 0 & v \\
\hline $2 / 1$ & 20 & 0 & 0 & 0 & 0 & 0 & 0 & 0 & 0 & \\
\hline $2 / 3$ & 1 & 0 & 0 & 0 & 0 & 0 & 0 & 0 & 0 & \\
\hline $3 / 5$ & 14 & 0 & 0 & 0 & 0 & 0 & 0 & 0 & 0 & $1 / 47$ \\
\hline $3 / 6$ & 3 & 0 & 0 & 0 & 0 & 0 & 0 & 0 & 0 & \\
\hline $4 / 5$ & 4 & 0 & 0 & 0 & 0 & 0 & 0 & 0 & 0 & \\
\hline $5 / 3$ & 5 & 0 & 0 & 0 & 0 & 0 & 0 & 0 & 1 & \\
\hline
\end{tabular}

${ }^{*} \mathrm{C}$ and $\mathrm{E}$ are variants of profile $\mathrm{A}$.

${ }^{\dagger} \mathrm{D}, \mathrm{F}$ and $\mathrm{H}$ are variants of profile $\mathrm{B}$.

Table 6. Biotypes and IS200 profiles of 53 isolates of serotypes Livingstone and Eimsbuettel of ribotype 1 (RT1) from different countries

\begin{tabular}{|c|c|c|c|c|}
\hline \multirow[b]{2}{*}{ Serotype } & \multirow[b]{2}{*}{ Country } & \multicolumn{3}{|c|}{ Number of isolates that were } \\
\hline & & tested & of RT/BT/IS200 type & in serotype \\
\hline Livingstone & $\begin{array}{l}\text { Scotland } \\
\text { Other }{ }^{\ddagger}\end{array}$ & $\begin{array}{r}18 \\
8 \\
6\end{array}$ & $\left.\begin{array}{l}\text { 1/8/A-var. }{ }^{\dagger} \\
1 / 8 / A \text {-var. } \\
1 / 3 / \text { B-var. }\end{array}\right\}$ & $\begin{array}{r}26 \\
6\end{array}$ \\
\hline Eimsbuettel & $\begin{array}{l}\text { Scotland } \\
\text { Other }^{+}\end{array}$ & $\begin{array}{c}19^{*} \\
1 \\
1\end{array}$ & $\left.\begin{array}{l}\text { 1/3/B-var. } \\
1 / 3 / \mathrm{B} \text {-var. }\end{array}\right\}$ & $\begin{array}{r}20 \\
1\end{array}$ \\
\hline
\end{tabular}

* Includes one isolate of RT6, a variant of RT1 [9].

${ }^{\dagger}$ A-var. includes variants $(\mathrm{C}, \mathrm{E})$ of $\mathrm{IS} 200$ profile $\mathrm{A}$; B-var. includes variants $(\mathrm{D}, \mathrm{F}, \mathrm{H})$ of $\mathrm{IS} 200$ profile B.

${ }^{+}$See Tables 1 and 2 . 
IS200 profiling with, e.g., ribotyping, would not have linked poultry to human infections by RT1 isolates in Scotland.

Whilst IS200 profiling was unhelpful for type discrimination in this study, it was extremely valuable for establishing clonal groupings: among RT1 isolates from sources in Scotland, a perfect correlation was found for the phenotypic and genotypic markers tested; all Livingstone isolates were of RT1/BT8/ IS200-A-var. (Table 6) and, hence, RT/BT/IS200 type was strongly predictive of serotype among RT1 isolates in Scotland. Consideration of another 16 isolates of RT1 collected during 1984-1992 [8,9] from countries other than Scotland confirmed the association between RT/BT/IS200-type and serotype. In all, there were only six Livingstone isolates that belonged to RT1/BT3/IS200-B-var. (Table 6) and only one Eimsbuettel isolate of type RT1/BT8/ IS200-A-var; gain or loss of phage 14 by occasional isolates of the subclones affords the most likely explanation for the finding of so few isolates of these 'rogue' serotypes. Thus, the only Eimsbuettel isolate of type RT1/BT8/IS200-A-var. was isolated from poultry in France in 1991 when Livingstone strains of the same RT/BT/IS200-type were present in diverse sources [8]; acquisition of phage 14 by any such Livingstone strain would have resulted in its phagemediated conversion to Eimsbuettel. Similarly, the origin of the few Livingstone isolates of RT1/BT3/ IS200-B-var. from Eimsbuettel strains of that same $\mathrm{RT} / \mathrm{BT} / \mathrm{IS} 200$ type is not difficult to imagine.

Most of the isolates of Livingstone and Eimsbuettel from countries other than Scotland, and a few Eimsbuettel isolates from Scotland, belonged to ribotypes RT2, RT3 and RT4. Within each ribotype, a few related biotypes were represented. Thus, 20 of 21 isolates of RT2 were of BT1 (one of the related BT3); and 21 isolates of the related ribotypes RT3 and RT4 $[8,9]$ were of the closely related biotypes BT5 (18 isolates) and BT6 (3). However, both serotypes were present in each RT/BT group. Further analysis of relatedness of Livingstone and Eimsbuettel clones of these ribotypes was not possible by IS200 profiling, because all isolates of RTs 2, 3 and 4 were IS200negative.

All but one member of the clone designated RT5/BT3 were isolated in Israel during 1968-1971, carried plasmids and were IS200-negative. The remaining isolate, also donated by colleagues in Israel, but originally isolated in USA from pet meal in 1991, was plasmid-free and had the unique IS200 profile L, not detected in any other isolate examined in this study. Representatives of the RT5/BT3 group have been found in serotype Livingstone only $[8,9]$.

In the few serotypes of Salmonella of serogroup C examined so far, results have shown that the distribu- tion of IS200 is limited $[18,19]$. For example, the major clone of Bovismorbificans (representing 93\% of strains examined) was IS200-negative, whereas two minor clones - very different from the major clone and from each other - were IS200-positive (one strain each), with no conserved bands in their profiles [18]. Again, in serotype Virchow only six of 57 phagetyped strains (not representing clonal groups) were IS200-positive and showed three different IS200 profiles containing low copy numbers of IS200 with no conserved bands [19]. However, among strains of serotype Infantis, 129 of 131 strains that represented five clonal lines found in Finland were IS200-positive; up to seven copies of IS200 were present in all strains, with four conserved, serotype-specific IS200 bands identified [20]. The findings of the present study show that the distribution of IS200 is also limited in strains of serotypes Livingstone and Eimsbuettel.

Our interest in serotypes Livingstone and Eimsbuettel arose because of their major contribution to human infections in Scotland during 1985-1993. Because the Scottish clone belonged to RT1, that ribotype may be somewhat over-represented in our collection compared with RTs 2-5 which, for the most part, were isolated in other countries. Nevertheless, the almost invariable association of IS200 of two quite different profiles with the two serotypes was impressive, suggesting that each subclone acquired its IS200 and antigenic markers at an early stage. Therefore, for the majority of IS200-positive strains of RT1 it was not possible to speculate if acquisition of antigenic characters preceded that of IS200 [5]. However, for the seven isolates whose serotype was unexpected for the RT/BT/IS200-type involved, it seems likely that the serotype-determining antigen $\mathrm{O} 14$ was acquired after the IS200 determinants. The findings that isolates of RT1 of both serotypes from sources outside Scotland were IS200-positive, and that isolates of RTs 2, 3 and 4 (regardless of their country of origin), were IS200negative, suggests that it was not the Scottish milieu but the genotype of the strains that influenced IS200 status.

We thank Dr J. Stanley, PHLS Central Public Health Laboratory, Colindale, London, for his generous gift of IS200 probe DNA and $\mathrm{Mr}$ H. Mather, Scottish Salmonella Reference Laboratory, Stobhill NHS Trust, Glasgow, for serotyping strains.

\section{References}

1. Lam S, Roth JR. IS200: a Salmonella-specific insertion sequence. Cell 1983; 34: 951-960.

2. Gibert I, Barbé J, Casadesús J. Distribution of insertion sequence IS200 in Salmonella and Shigella. J Gen Microbiol 1990; 136: 2555-2560.

3. Gibert I, Carroll K, Hillyard DR, Barbé J, Casadesus J. IS200 is not a member of the IS 600 family of insertion sequences. Nucleic Acids Res 1991; 19: 1343.

4. Threlfall EJ, Powell NG, Rowe B. Differentiation of salmonellas by molecular methods. PHLS Microbiology Digest 1994; 11: $199-202$. 
5. Stanley J, Saunders N. DNA insertion sequences and the molecular epidemiology of Salmonella and Mycobacterium. $J$ Med Microbiol 1996; 45: 236-251.

6. McAllister TA, Roud JA, Marshall A, Holland BM, Turner TL. Outbreak of Salmonella eimsbuettel in newborn infants spread by rectal thermometers. Lancet 1986; 1: 1262-1264.

7. Old DC, Porter-Boveri M, Munro DS. Human infection in Tayside, Scotland due to Salmonella serotype Livingstone. $J$ Med Microbiol 1994; 40: 134-140.

8. Crichton PB, Old DC, Taylor A, Rankin SC. Characterisation of strains of Salmonella serotype Livingstone by multiple typing. J Med Microbiol 1996; 44: 325-331.

9. Old DC, Crichton PB, Taylor A, Rankin SC. Phenotypic and genotypic discrimination of strains of Salmonella serotype Eimsbuettel from human and animal sources. $J$ Med Microbiol 1997; 46: 617-622

10. Wilson K. Preparation of genomic DNA from bacteria. In Ausubel FM, Brent R, Kingston RE et al. (eds) Current protocols in molecular biology 1987-1988, vol 1. New York, Wiley. 1987: 2.4.1-2.4.5

11. Miller JH. Experiments in molecular genetics. Cold Spring Harbor, NY, Cold Spring Harbor Laboratory. 1972: 433.

12. Stanley J, Burnens A, Powell N, Chowdry N, Jones C. The insertion sequence IS200 fingerprints chromosomal genotypes and epidemiological relationships in Salmonella heidelberg. $J$ Gen Microbiol 1992; 138: 2329-2336.

13. Sambrook J, Fritsch EF, Maniatis T. Molecular cloning: a laboratory manual, 2nd edn, vol 3. Cold Spring Harbor, NY, Cold Spring Harbor Laboratory. 1989: B. 13.

14. Stanley J, Baquar N, Burnens A. Molecular subtyping scheme for Salmonella panama. J Clin Microbiol 1995; 33: $1206-$ 1211.

15. Le Minor L. Conversions antigéniques chez les Salmonella. VII. Acquisition du facteur 14 par les Salmonella du sousgroupe $C_{1}(6,7)$, après lysogénisation par un phage tempéré isolé de cultures du sous-groupe $\mathrm{C}_{4}[6,(7),(14)]$. Ann Inst Pasteur 1965; 109: 505-515.

16. Popoff MY, Le Minor L. [Antigenic formulas of the Salmonella serovars, 6th revision.] WHO Collaborating Center for Reference and Research on Salmonella. Paris, Institut Pasteur, 1992.

17. Anon. Salmonella serotypes recorded in the PHLS Salmonella data sets. Communicable Disease Report CDR Wkly 1997; 7: 338.

18. Ezquerra E, Burnens AP, Frith K, Costas M, Stanley J. Molecular genotype analysis of Salmonella bovismorbificans. Mol Cell Probes 1993; 7: 45-54.

19. Torre E, Threlfall EJ, Hampton MD, Ward LR, Gibert I, Rowe B. Characterization of Salmonella virchow phage types by plasmid profile and IS200 distribution. J Appl Bacteriol 1993; 75: $435-440$.

20. Pelkonen S, Romppanen E-L, Siitonen A, Pelkonen J. Differentiation of Salmonella serovar Infantis isolates from human and animal sources by fingerprinting IS200 and $16 \mathrm{~S} \mathrm{rrn}$ loci. J Clin Microbiol 1994; 32: 2128-2133. 